\title{
RING PRIMA DAN RING SEMIPRIMA
}

Prime Rings and Semi-Prime Rings

\author{
ELVINUS RICHARD PERSULESSY ${ }^{1}$, ABDUL HALIM MAHMUD ${ }^{2}$ \\ ${ }^{I}$ Staf Jurusan Matematika FMIPA UNPATTI \\ Jl. Ir. M. Putuhena, Kampus Unpatti, Poka-Ambon, Maluku \\ ${ }^{2}$ Pegawai BPS Kabupaten Buru Provinsi Maluku \\ Jl. Sultan Babullah No. 1, Namlea - Kabupaten Buru, Maluku \\ e-mail: richardelvinus@yahoo.com
}

\begin{abstract}
ABSTRAK
Penelitian ini membahas ring prima dan ring semiprima . Jika pada ring $\boldsymbol{R}$, ditambahkan satu aksioma lagi yaitu perkalian tiga elemen dalam ring $\boldsymbol{R}$ dengan karakteristik tertentu yang menghasilkan nol, maka diperoleh struktur baru yang dikenal dengan nama ring prima dan ring semiprima. Setiap daerah integral adalah ring prima. Ring prima adalah ring semiprima tapi sebaliknya belum tentu berlaku.
\end{abstract}

Kata kunci : Daerah Integral, Ring Prima, Ring Semiprima.

\section{PENDAHULUAN}

Teori grup dan teori ring merupakan teori-teori yang sudah sangat dikenal dalam struktur aljabar. Pengembangan kedua teori inipun terus dilakukan. Hal ini dapat dilihat dari munculnya struktur-struktur baru yang dikembangkan dari kedua teori ini.

Jika pada ring $R$, ditambahkan satu aksioma lagi yaitu perkalian tiga elemen dalam ring $R$ yang hasilnya nol, tidak perlu elemen di tengah adalah nol, tetapi dua elemen yang lain salah satunya tentu nol, maka diperoleh struktur baru yang dikenal dengan nama ring prima.Selain ring prima, ternyata jika elemen kanan dan kiri adalah sama, tidak perlu elemen di tengah adalah nol, tetapi elemen yang lain tentu nol, maka struktur baru ini disebut ring semiprima.

Walaupun hanya ditambahkan satu aksioma, namun hal ini membuat perbedaan yang sangat mendasar antara ring, ring prima dan ring semiprima. Selain itu, banyak sifat-sifat yang muncul dalam ring prima dan ring semiprima yang diperoleh dengan cara membandingkan sifat-sifat yang ada dalam ring. Hal-hal tersebut yang melatarbelakangi penelitian ini.

\section{TINJAUAN PUSTAKA}

Istilah ring pertama kali diperkenalkan oleh David Hilbert (1862-1943), tetapi sebatas pendekatan definisi yang masih abstrak. Himpunan $R$ dikatakan ring jika terhadap operasi penjumlahan dan pergandaan yang didefinisikan padanya, $R$ memenuhi sifat-sifat yaitu terhadap operasi penjumlahan, $R$ adalah grup abelian, terhadap operasi pergandaan $R$ memenuhi sifat tertutup dan asosiatif serta terhadap operasi penjumlahan dan pergandaan $R$ memenuhi sifat distributif kiri dan distributif kanan. (Fraleigh, 2000)

Dari ring $R$ dapat dibentuk struktur baru yang dinamakan ring prima jika ditambahkan satu sifat yaitu perkalian tiga elemen di $R$ yang hasilnya nol, tidak perlu elemen di tengah adalah nol, tetapi dua elemen yang lain salah satunya tentu nol. Selain itu dapat dibentuk pula struktur baru yang dinamakan ring semiprima jika pada ring $R$ ditambahkan sifat yaitu perkalian tiga elemen di $R$ yang hasilnya nol, jika elemen kanan dan kiri adalah sama, tidak perlu elemen di tengah adalah nol, tetapi elemen yang lain tentu nol. (Thaheem, 2005). Ring prima adalah ring semiprima, tapi sebaliknya belum tentu berlaku. (Atteya, 2010)

\section{Definisi 1 (Ring)}

Himpunan $R \neq \varnothing$ dengan dua operasi biner, penjumlahan "+" dan pergandaan "." disebut mempunyai struktur suatu ring, selanjutnya $R$ disebut Ring (Gelanggang) jika memenuhi aksioma-aksioma:

I. Terhadap penjumlahan $\langle R,+\rangle$ merupakan grup abelian, yaitu

1. Tertutup

$$
(\forall a, b \in R)(\exists ! c \in R) a+b=c
$$


2. Asosiatif $(\forall a, b, c \in R)(a+b)+c=a+(b+c)$

3. Ada elemen netral $(\exists e \in R)(\forall a \in R) e+a=a+e$

4. Setiap elemen $R$ mempunyai invers $(\forall a \in R)(\exists-a \in R) a+(-a)=(-a)+a=0$

5. Komutatif, $(\forall a, b \in R) a+b=b+a$

II. Terhadap pergandaan $\langle R, \cdot\rangle$ memenuhi sifat

6. Tertutup $(\forall a, b \in R)(\exists ! c \in R) a \cdot b=c$

7. Asosiatif $(\forall a, b, c \in R)(a \cdot b) \cdot c=a \cdot(b \cdot c)$

III. Distributif

8. Distributif kiri

$(\forall a, b, c \in R) a \cdot(b+c)=a \cdot b+a \cdot c$

9. Distributif kanan

$(\forall a, b, c \in R)(a+b) \cdot c=a \cdot c+b \cdot c$

\section{Teorema 1}

a. Elemen satuan dalam ring $R$ adalah tunggal

b. Invers suatu elemen dalam ring $R$ adalah tunggal

c. Misalkan $R$ adalah ring dengan elemen satuan dan $a, b \in R$. Jika $a$ dan $b$ masing-masing mempunyai invers maka $a b$ juga mempunyai invers yaitu $(a b)^{-1}=b^{-1} a^{-1}$.

\section{Teorema 2}

Jika $R$ ring dan 0 elemen netral terhadap penjumlahan, maka $(\forall a, b, c \in R)$ berlaku

i) $a \cdot 0=0 \cdot a=0$

ii) $a(-b)=-a b ;(-a) b=-a b$

iii) $(-a)(-b)=a b$

iv) $a(b-c)=a b-a c$

\section{Teorema 3}

Jika $R$ ring dengan elemen satuan 1 dan $a \in R$ maka

i) $(-1) a=-a$

ii) $(-1)(-1)=1$

\section{Definisi 2 (Senter Dari Ring)}

Jika $R$ ring, senter dari $R$ adalah $Z(R)$, yang didefinisikan oleh

$$
Z(R)=\{z \in R \mid z x=x z, \forall x \in R\}
$$

\section{Definisi 3}

\section{(Ring Yang Tidak Memuat Pembagi Nol Sejati)}

Ring $R$ tidak memuat pembagi nol sejati, jika memenuhi

$$
(\forall a, b \in R)[a b=0 \Rightarrow a=0 \vee b=0]
$$

atau

$$
(\forall a, b \in R)[(a \neq 0 \wedge b \neq 0) \Rightarrow a b \neq 0]
$$

\section{Definisi 4 (Nilpoten)}

Elemen $a$ dalam ring $R$ disebut nilpoten (nilpotent) jika terdapat bilangan $n \in Z^{+}$sedemikian hingga $a^{n}=0$.

\section{Teorema 4}

Jika $R$ ring, $0 \in R$ adalah nilpoten dan jika $a$ nilpoten maka $a$ adalah pembagi nol.

\section{HASIL DAN PEMBAHASAN}

\section{Ring Prima}

Definisi 5

Ring $R$ adalah prima jika memenuhi

$$
(\forall a, b \in R)[a R b=0 \Rightarrow(a=0 \vee b=0)] .
$$

Selanjutnya ring prima (prime ring) $R$ dinotasikan dengan $R_{p}$.

\section{Contoh 1}

Diberikan $R$ ring komutatif yang tidak memuat pembagi nol sejati dan $a \in R$ tertentu. Jika diketahui $(\forall x \in$ $R$ ) $a x=0$. Akan ditunjukkan $R$ ring prima.

Penyelesaian:

Diketahui $(\forall x \in R) a x=0$.

Jika kedua ruas dikalikan dengan $b \in R$ dari kanan diperoleh

$$
a x b=0
$$

Karena $R$ ring yang komutatif berlaku

$$
a b x=0
$$

Atau dapat pula ditulis

$$
a b x=0 \cdot x
$$

Dengan menggunakan hukum kanselasi kanan diperoleh

$$
a b=0
$$

Karena $R$ ring yang tidak memuat pembagi nol sejati diperoleh

$$
a=0 \vee b=0
$$

Jadi $R$ ring prima.

\section{Ring Semiprima}

Definisi 6

Ring $R$ adalah semiprima jika memenuhi

$$
(\forall a \in R)[a R a=0 \Rightarrow a=0] \text {. }
$$

Selanjutnya ring semiprima (semiprime ring) $R$ dinotasikan dengan $R_{S}$

\section{Contoh 2}

Diberikan himpunan bilangan real $\mathrm{R}$ dan $a \in \mathrm{R}$. Jika diketahui $(\forall x \in \mathrm{R}) a x=0$. maka $\mathrm{R}$ ring semiprima.

\section{Lemma 1}

Diberikan $R_{S}$ ring semiprima dan $a \in R_{s}$ sedemikian hingga

$$
\left(\forall x, y \in R_{S}\right)[x a y=0 \Rightarrow a=0] \text {. }
$$

Bukti.

Diketahui $\left(\forall x, y \in R_{s}\right) x a y=0$

Akan ditunjukkan $a=0$.

Jika kedua ruas pada persamaan $x a y=0$ dikalikan $a y \in R_{s}$ dari kiri diperoleh

$$
\text { (ay) } x a y=0
$$

Karena $R_{s}$ adalah ring semiprima, menurut Definisi 6 diperoleh

$$
a y=0
$$


Jika kedua ruas dikalikan $a \in R_{S}$ dari kanan diperoleh

$$
\text { aya }=0
$$

Karena $R_{s}$ adalah ring semiprima menurut Definisi 6 diperoleh

$$
a=0
$$

\section{Ring Prima Dan Ring Semiprima \\ Teorema 5}

Setiap daerah integral $D$ adalah ring prima.

Bukti.

Diketahui $D$ adalah daerah integral. Jadi $D$ adalah ring yang memenuhi

i) $\quad D$ mempunyai elemen satuan

ii) $D$ komutatif

iii) $\quad D$ tidak memuat pembagi nol sejati.

Akan ditunjukkan $D$ adalah ring prima atau $(\forall a, b, x \in$ $R)[a x b=0 \Rightarrow(a=0 \vee b=0)]$

Diketahui $(\forall a, b, x \in R) a x b=0$

Menurut (ii) $(\forall a, b, x \in R) a b x=0$

atau dapat ditulis $(\forall a, b, x \in R) a b x=0 . x$

Dengan menggunakan hukum kanselasi kanan diperoleh $(\forall a, b \in R) a b=0$

Menurut (iii) $(\forall a, b \in R) a=0 \vee b=0$.

Jadi $D$ ring prima.

\section{Contoh 3}

Himpunan bilangan real $\mathrm{R}$, himpunan bilangan bulat $Z$, himpunan bilangan rasional $\mathrm{Q}$, himpunan bilangan kompleks $\mathrm{C}$, dan himpunan bilangan bulat diredusir modulo $n, Z_{n}$ dengan $n$ prima merupakan daerah integral. Sebagai akibatnya $\mathrm{R}, Z, \mathrm{Q}, \mathrm{C}$ dan $Z_{n}$, dengan $n$ prima adalah ring prima.

\section{Teorema 6}

Ring prima adalah ring semiprima.

Bukti.

Diketahui $R_{p}$ adalah ring prima atau

$$
\left(\forall a, b, x \in R_{p}\right)[a x b=0 \Rightarrow(a=0 \vee b=0)]
$$

Akan ditunjukkan $R_{p}$ adalah ring semiprima atau

$$
\left(\forall a, x \in R_{p}\right)[a x a=0 \Rightarrow a=0]
$$

Diketahui $\left(\forall a, x \in R_{p}\right) a x a=0$

Karena $R_{p}$ adalah ring prima. maka diperoleh $a=0$

Jadi $R_{p}$ adalah ring semiprima.

\section{Contoh 4}

Karena ring prima adalah ring semiprima, sebagai akibatnya $\mathrm{R}, Z, \mathrm{Q}, \mathrm{C}$ dan $Z_{n}$ dengan $n$ prima adalah ring semiprima.

\section{Lemma 2}

Diberikan $R_{s}$ ring semiprima dan $\in R_{s}$. Jika $a^{2}=0$ maka $a \in Z\left(R_{s}\right)$.
Bukti.

Diketahui $R_{S}$ ring semiprima dan $\left(\forall a \in R_{S}\right) a^{2}=0$

Akan ditunjukkan $a \in Z\left(R_{S}\right)$.

Dengan menggunakan hukum kanselasi kanan diperoleh

$$
\left(\forall a \in R_{s}\right) a=0
$$

Jika kedua ruas dikalikan $x \in R_{S}$ dari kanan diperoleh

$$
\left(\forall a, x \in R_{s}\right) a x=0
$$

Selanjutnya diperoleh $a x=x a$

Dengan demikian $a \in Z\left(R_{s}\right)$.

\section{Lemma 3}

Senter dari ring semiprima terdiri dari elemen-elemen nilpoten bukan nol.

Bukti.

Diketahui $Z\left(R_{S}\right)$ adalah senter dari ring semiprima yang didefinisikan oleh

$$
Z\left(R_{s}\right)=\left\{a \in R_{s} \mid a^{n}=0, \forall n \in Z^{+}\right\}
$$

Ambil sebarang $a \in Z\left(R_{s}\right)$

Akan ditunjukkan $a \neq 0$

$$
a \in Z\left(R_{s}\right) \Rightarrow\left(\forall n \in Z^{+}\right) a^{n}=0
$$

Dengan demikian

$$
\left(\forall a \in R_{S}\right)\left(\forall n \in Z^{+}\right) a \cdot a^{n-1}=0
$$

Jika kedua ruas dikalikan dengan $b \in R_{S}$ dari kanan diperoleh

$$
\left(\forall a \in R_{S}\right)\left(\forall n \in Z^{+}\right) a \cdot a^{n-1} \cdot b=0
$$

Dengan menggunakan Lemma 1 diperoleh

$$
\left(\forall a \in R_{S}\right)\left(\forall n \in Z^{+}\right) a^{n-1}=0
$$

Gunakan persamaan (ii) dalam persamaan (i) diperoleh

$$
a \neq 0
$$

Jadi senter dari ring semiprima terdiri dari elemen-elemen nilpoten bukan nol.

\section{KESIMPULAN}

Dengan berpegang pada definisi-definisi dan teorema-teorema yang ada dapat diambil kesimpulan sebagai berikut.

Ring prima adalah ring semiprima, tapi sebaliknya belum tentu berlaku. Selanjutnya karena setiap daerah integral adalah ring prima, maka setiap lapangan adalah ring prima.

\section{DAFTAR PUSTAKA}

Atteya, M. J. 2010. On Generalized Derivations of Semiprime Rings. International Journal of Algebra, 4(12) : 591-598. 
Fraleigh, J.B. 2000. A First Course In Abstract Algebra. Sixth Edition. Addison-Wesley Publishing Company, Massachussets.

Thaheem, A.B. 2005. On Some Properties Of Derivation On Semiprime Rings. Southeast Asian Bulletin of Mathematics, 29(6) : 1143-1152. 